\title{
A Risk-Adjusted Performance Evaluation Of US And EU Hedge Funds And Associated Equity Markets Over The 2007-2009 Financial Crisis
}

Chris van Heerden, North West University, South Africa André Heymans, North West University, South Africa Gary van Vuuren, North West University, South Africa Wilmé Brand, North West University, South Africa

\begin{abstract}
Hedge funds are considered to be market-neutral due to their unrestricted investment flexibility and more efficient market timing abilities (Ennis \& Sebastian, 2003). They may also be considered as suitably unconventional assets for improving portfolio diversification (Lamm, 1999). The evidence from this study confirms the dominance of hedge funds over the CAC 40, DAX, S\&P 500 and Dow Jones from 2004 to 2011. Overall, the Sharpe, Sortino, Omega, Jensen's alpha, Treynor and Calmar ratios illustrate that US hedge funds outperformed both EU hedge funds and the associated equity markets over this period. Evidence was also found that both US and EU hedge funds were more correlated with the S\&P 500 and Dow Jones after the financial crisis of 20072009 than before the crisis.
\end{abstract}

Keywords: Hedge Funds; Omega.

\section{INTRODUCTION}



edge funds are defined as pooled investment vehicles that embody a variation of different investment strategies, which can include short and long positions, leveraged positions, and derivate positions to limit market exposure and to increase risk-adjusted returns (Amin \& Kat, 2003; National Treasury, 2012). With no investment constraints, a hedge fund manager is capable of investing in any global market to maximise a fund's financial gains (Kanellakos, 2005). This implies that the different investment strategies available can satisfy a variation of investors with different risk preferences (Shin, 2012). As such, hedge funds are considered unconventional assets that contribute to a higher reward level, which can serve as a substitute for cash and bonds during a declining equity market (Lamm, 1999).

However, the certainty of performance persistence has been diluted by the many conflicting results found by past studies. On the one hand the proponents of hedge funds argue that their low correlation with the returns on traditional alternative assets, like currencies, bonds, mutual funds and other equities, therefore, make them a better risk-return trade-off vehicle (Fung \& Hsieh, 1997; Lavino, 2000; Amin \& Kat, 2003; Al-Sharkas, 2005). This low correlation with the rest of the asset universe is further enhanced because of their exemption from the Company Act of 1940 and from the Security Exchange Act of 1934, providing them greater flexibility regarding different investment options.

It is also argued that hedge funds generate positive alphas, which implies that hedge fund managers as a group have an investment ability and may possess private information that is unavailable to other investors $(\mathrm{Li}$, 2006), thus emphasising the potential dominance of hedge funds. Also, with the possibility of implementing features, like lock up periods, redemption frequencies and notices, share restrictions and minimum investment 
amounts, hedge funds can produce higher alphas as they earn an illiquidity premium (see Agarwal, Daniel \& Naik, 2009; Li, 2006; Aragon, 2007). These arguments, therefore, suggest that with a higher level of illiquidity and investment flexibility hedge funds should be able to ensure performance persistence and dominance over other types of investment options. This is also emphasised by Ackermann, McEnally and Ravenscraft (1999) and Liang (1999) who found that hedge funds have the consistency of providing superior returns with higher volatility, due to their more active management approach, compared to the more passive managed mutual funds.

Studies conducted by McCarthy and Spurgin (1998) and Schneeweis and Spurgin (1998) also concluded that hedge funds can offer greater risk-adjusted returns than alternative investment options, thus incorporating a lower level of systematic risk (Brown, Goetzmann \& Ibbotson, 1999; Liang, 1999). This is mainly possible because of their investment flexibility, their ability to hedge themselves in bear markets (Nicholas, 2004), as well as their superior market timing (Ennis \& Sebastian, 2003).

There are also a number of other studies that argue for the superiority of hedge funds over other investment vehicles. Studies done by Ackermann, McEnally and Ravenscraft (1999), Edwards and Caglayan (2001a), Fung and Hsieh (2004) and Kosowski, Naik and Teo (2007) for example all found performance persistence in hedge funds. There are also those studies that found performance persistence to vary based on the market environment and differences in investment strategies (see for example Fung \& Hsieh, 1997). Corroborating these findings, the study by Capocci, Corhay and Hübner (2005) reports evidence of yearly-based persistence in mid-performed particular hedge fund portfolios during bullish periods, while Duong (2008) found stronger performance persistence when monthly, quarterly or semi-annual returns are used instead of annual return data. Further evidence even suggested that performance persistence might decrease over a longer period (Agawal \& Naik, 2000).

On the opposite side of the argument, evidence also abounds that performance persistence does not manifest at all among hedge funds. Brown, Goetzmann and Ibbotson (1999) and Schneeweis, Kazemi and Martin (2001), for example found no evidence of performance persistence for hedge funds. Edwards and Caglayan (2001b) also found that hedge funds are highly correlated with an equity market during a bear market, implying a downturn in returns during a downswing in the equity market. The main reason for the uncertainty regarding performance persistence of hedge funds, however, mainly stems from the high attrition rate among hedge funds (see Brown, Goetzmann, Ibbotson \& Ross, 1992; Fung \& Hsieh, 1997; Ackermann, McEnally \& Ravenscraft 1999; Liang, 2000; $\mathrm{Li}, 2006$ ). This implies that there is a relative high tendency for a significant number of hedge funds to close over a certain time period. Some of the reasons for the high attrition rate can be attributed to voluntary dropouts or due to poor performance, but not because hedge funds are associated as defunct funds (Li, 2006). Though, Amin and Kat (2003) argue that the aggressive attitude of hedge fund managers may be a significant factor that contributes to a high attrition rate.

Given the contrasting results above, it is difficult to assess whether hedge funds are indeed superior investment vehicles. Overall, hedge funds employ highly skilled managers (Shin, 2012), and are excluded from the regulations governing public issuance of securities (Duong, 2008), which allows them to employ a myriad of techniques that allow them to outperform 'normal' investment vehicles.

This study will, evaluate both United States (US) and European (EU) hedge funds over three different periods to establish performance dominance during different market trends. The performance of these hedge funds will be evaluated by employing the Sharpe ratio, Sortino ratio, Treynor ratio, Jensen's alpha, Calmar ratio, Omega ratio and an Exponential-Weighted Moving Average (EWMA) model. These hedge fund's performances will be measured over the pre-financial crisis, financial crisis and post-financial crisis periods, respectively, in order to establish if the 2007 - 2009 financial crisis, which originated in the US, and the current (2012) debt crisis in the EU have influenced performance dominance. Furthermore, by evaluating these hedge funds against the DAX, CAC 40, S\&P 500 and the Dow Jones, it is possible to establish whether hedge funds outperformed associated equity markets and if a normal buy-and-hold-strategy on these equity markets were the better option than to invest in a US or EU hedge fund. In order to achieve these objectives this paper will commence by discussing the most dominant riskadjusted performance measures as emphasised by past studies (Section 2). The empirical results will then be reported in Section 3, followed by the concluding remarks and recommendations in Section 4. 


\section{RISK-ADJUSTED PERFORMANCE MEASURES}

The Sharpe ratio remains one of the most commonly used statistics in financial analysis. It is, therefore, not surprising that market participants - whether investors or fund managers - still employ the Sharpe ratio as the performance measure of choice (see for example Lo, 2002; Bailey \& López de Prado, 2012, p. 3; Schuster \& Auer, 2012; Auer \& Schuhmacher, 2013). Before Sharpe formulated his famous ratio, Jack Treynor developed the Treynor ratio in 1965. This ratio is identical to the ratio Sharpe developed in 1966, but differs with respect of the risk measure used. The Treynor ratio can be expressed as (adapted from Treynor, 1965):

Treynor ratio $=\frac{R_{p}-r_{f}}{\beta_{p}}$

where $r_{p}$ denotes the return of a portfolio or security; $r_{f}$ denotes the risk-free rate; and $\beta_{p}$ is utilised as risk metric, thus incorporating market risk. Sharpe's ratio veers away from market risk, only considering the volatility of the portfolio around its own mean as a risk measure. The Sharpe ratio can thus be expressed as (adapted from Sharpe, 1966):

Sharpe ratio $=\frac{R_{p}-r_{f}}{\sigma_{p}}$

where $\sigma_{p}$ is the standard deviation of portfolio returns. Sharpe's ratio thus allows for the measurement of the risk premium of the portfolio, for every unit of risk assumed. Therefore, it is obvious that, like with Treynor's ratio, the portfolio with the greater Sharpe value will be the best performing portfolio on a risk-adjusted basis. However, although these two measures are so alike, they do not always render similar results. It is thus possible for a portfolio with a relatively large unique risk to outperform the market when looking at the Treynor's ratio, but underperform the market when using Sharpe's ratio (Deb, 2012).

Despite the Sharpe ratio's popularity, there are still some pitfalls to consider when applying it as performance measure in cases where its underlying assumptions are breached (Auer \& Schuhmacher, 2013, p. 154; Schuster \& Auer, 2012, p. 124). As such the Sharpe ratio generally fares better in ranking the performance of less volatile returns (such as that of mutual funds), but poorer when highly volatile returns are gauged (Lo, 2002, p. 36). Since hedge funds make use of derivative instruments, their returns often follow an asymmetrical distribution with fat tails (thus a non-normal distribution), thus reducing the Sharpe ratio's ability to handle these returns (Fung \& Hsieh, 1999a; Eling, 2008). In such circumstances, the Sharpe ratio tends to overestimate true risk (Brooks \& Kat, 2002). This leaves market participants, with a skewed perception of the real risk inherent in hedge funds.

It is, therefore, necessary to look wider than the standard Sharpe ratio when comparing hedge fund performance with anything. To this end, several studies have included a variety of measures to gauge the performance of hedge funds. Gregoriou and Rouah (2002), for example employed both the Sharpe ratio and the Treynor ratio while Brown, Goetzmann and Ibbotson (1999) used the Sharpe ratio and Jensen's alpha. In their paper on the influence of different performance measures on the evaluation of hedge funds, Eling and Schuhmacher (2007) employed thirteen different performance measures, and reported that the rankings according to the Sharpe ratio and the other performance measures were very similar. ${ }^{1}$ Eling (2008) also went on to test the performance rankings of a wider population of asset classes including stocks, bonds, real estate, hedge funds, funds of hedge funds, Commodity Pool Operators (CPOs) and Commodity Trading Advisors (CTAs) by employing eleven performance measures including the Sharpe ratio. ${ }^{2}$ Moreover, there have also been studies, like Sedzro (2009), who have consulted not only the Sharpe ratio and Modified Sharpe ratio, but have used additional statistical models, like the Data Envelopment Analysis (DEA) method and the Stochastic Dominance (SD) method, to generate performance rankings.

\footnotetext{
${ }^{1}$ Eling and Schuhmacher (2007) employed the standard Sharpe ratio, the modified Sharpe ratio, the Treynor ratio, Jensen's alpha, the Sortino ratio, Kappa 3, the upside potential ratio, the Calmar ratio, the Sterling ratio, the Burke ratio, the excess return on value at risk, the conditional Sharpe ratio and Omega.

${ }^{2}$ Eling (2008) employed the modified Sharpe ratio, the Sortino ratio, Kappa 3, the upside potential ratio, the Calmar ratio, the Sterling ratio, the Burke ratio, the excess return on value at risk, the conditional Sharpe ratio and Omega against the Sharpe ratio as a benchmark.
} 
In order to measure the impact of the 2007-2009 financial crisis on hedge funds a combination of ratios used by Eling and Schuhmacher (2007), Brown, Goetzmann and Ibbotson (1999), as well as Gregoriou and Rouah (2002) were chosen. These ratios were selected to rank the sample of hedge fund and market index returns in order to escape some of the shortcomings of using only Sharpe in modelling volatile returns. Also, to extent the risk perception and the shortcomings of the Sharpe and Treynor ratio additional ratios were also employed.

\subsection{Measures other than Sharpe and Treynor}

Where Treynor and Sharpe's indexes provide measures for ranking the relative performances of various portfolios on a risk-adjusted basis, Jensen (1968) attempted to construct a measure of absolute performance on a risk-adjusted basis, i.e., a definite standard against which performances of various portfolios can be measured. This standard is based on measuring the 'portfolio manager's predictive ability' (the ability to earn returns through successful prediction of security prices), which are higher than those expected, given the level of riskiness of his portfolio, the expectation being based on the Capital Asset Pricing Model (CAPM).

This is an attempt to determine if returns, more than that expected based on CAPM, are being earned for the portfolio's riskiness. A simplified version of his basic model is given by (adapted from Jensen, 1968):

$R_{p}-r_{f}=\alpha_{p}+\beta_{p} \cdot\left(R_{m}-r_{f}\right)$

where $R_{p}$ is the average portfolio return for the period concerned; $r_{f}$ is the risk-free rate for the same period; $R_{m}$ is the average market return or the return of the index for the portfolio concerned for the same period; and $\alpha_{p}$ is the Jensen's Alpha.

The $\alpha_{p}$ based on CAPM, on average, should be zero in the long-run, indicating neutral performance by a portfolio, i.e., the portfolio has done just as well as an unmanaged market portfolio or a large, randomly selected portfolio manager with a naive buy-and-hold strategy. A positive value of $\alpha_{p}$ represents a superior performance on the part of the portfolio manager. On the other hand, a negative value of $\alpha_{p}$ indicates inferior management performance, because management did not do as well as an unmanaged portfolio of equal systematic risk.

The Sortino ratio differs from Sharpe in another way: it applies downside deviation as denominator instead of overall standard deviation. It, therefore, only considers "bad" volatility (Sortino \& Van der Meer, 1991, p. 29), thus solving for the asymmetric characteristics of the return distribution of hedge funds, as is clear in Equation 4 below (adapted from Eling \& Schuhmacher, 2007):

Sortino ratio $=\frac{r_{i}^{d}-r_{f}}{\sqrt[n]{L P M_{n i}(\tau)}}$

where $r_{f}$ is the risk free rate and the Lower Partial Moment (LPM) can be written as:

$L P M_{n i}(\tau)=\frac{1}{T} \sum_{t=1}^{T} \max \left[\tau-r_{i t}, 0\right]^{n}$

The Sortino ratio's ability to capture downside risk lays in the fact that it uses a LPM of the second order (thus $n=2$ ) to capture the semi-variance of returns. Since LPMs only consider negative deviations from a minimal acceptable return (normally a risk free rate), it trumps standard deviation that captures both positive and negative deviations of expected returns. The other ratio used that employs LPMs is Omega.

Omega does not only capture LPMs, but also Higher Partial Moments (HPMs), thus taking the positive deviations of expected returns above a minimal acceptable returns into consideration. In doing this, Omega provides a risk-reward evaluation that incorporates both the beneficial impact of gains and the unfavourable effect of losses, relative to any investor's threshold (Shadwick \& Keating, 2002). The ability of Omega to capture both sides of the 'Partial Moment coin' is visible from Equation 6 below (Eling \& Schuhmacher, 2007): 
Omega $=\frac{r_{i}^{d}-\tau}{L P M_{n i}(\tau)}+1$

where the LPM can once again be written as:

$L P M_{n i}(\tau)=\frac{1}{T} \sum_{t=1}^{T} \max \left[\tau-r_{i t}, 0\right]^{n}$

In this case the LPM of the order is observed. It should be clear from Equation 6 that Omega allows the user to specify the level of return against which a given outcome will be considered a profit or a loss, and is thus in essence a probability weighted ratio of profits to losses relative to a return threshold (Bertrand \& Prigent, 2011).

The other measure employed that uses LPMs in the form of a maximum drawdown is the Calmar ratio. This ratio allows the user to express excess returns as a function of the maximum cumulative loss between a peak and a following bottom. The Calmar ratio can, therefore, be easily expressed as follows (adapted from Eling, 2008):

Calmar ratio $=\frac{R_{p}-r_{f}}{-D_{p}}$

where $R_{p}$ is the average portfolio return for the period concerned; $r_{f}$ is the risk-free rate for the same period, and $-D_{p}$ is the maximum drawdown. Although Magdon-Ismail and Atiya (2004) cautions against the use of the Calmar ratio in the form above, this issue is not applicable in our case since all comparisons are done over the same time frames. ${ }^{3}$

The final performance measure to be used is the EWMA model of JP Morgan. This model can provide substantial assistance in portfolio allocation and performance, even outperforming multivariate Generalised AutoRegressive Conditional Heteroskedasticity (GARCH) models (Giamouridis \& Vrontos, 2007). This model can be illustrated as follows (J.P. Morgan/Reuters, 1996):

$\sigma=\sqrt{(1-\lambda) \sum_{t=1}^{T} \lambda^{t-1}\left(r_{t}-\bar{r}\right)^{2}}$

where the EWMA model depends on the decay factor, $\lambda(0<\lambda<1)$, which determines the relative weights that must be applied to returns. In estimating the decay factor the following steps must be followed (J.P. Morgan/Reuters, 1996):

Firstly, $\Pi$ must be calculated. This can be achieved by taking the sum of all $\mathrm{N}$ minimal Root-Mean-SquareErrors (RMSE), $\tau$ 's:

$$
=\sum_{i=1}^{N} \tau_{i}
$$

where

$\operatorname{RMSE}_{v}=\frac{1}{T} \sum_{t=1}^{T}\left(r_{t+1}^{2}-\hat{\sigma}_{(t+1 \mid t)}^{2}\right)^{2}$

Then, the relative error measure must be defined as follows:

$\Theta_{i}=\frac{\tau_{i}}{\sum_{i=1}^{N} \Theta_{i}^{-1}}$

\footnotetext{
${ }^{3}$ Magdon-Ismail and Atiya (2004) introduced a normalised Calmar ratio in order to circumvent the issue of comparing Calmar ratios over different periods.
} 
Once the relative error measure is defined, the weight should be defined as follows:

$\phi_{i}=\frac{\Theta_{i}^{-1}}{\sum_{i=1}^{N} \Theta_{i}^{-1}}$

where

$\sum_{i=1}^{N} \phi_{i}=1$

Finally, the optimal decay factor $\tilde{\lambda}$ can be defined as:

$$
=\sum_{i=1}^{N} \phi_{i} \tilde{\lambda}_{i}
$$

where the final optimal decay factor applied is the weighted average of individual optimal decay factors.

\section{DATA AND RESULTS}

The time series under investigation will be structured to incorporate two aspects that can affect hedge fund performance. Firstly, the data series were divided into three periods, where two of these periods incorporated a bullish phase and one incorporated a bearish phase. This approach was motivated by two previous studies. Although there is evidence that hedge funds are highly correlated with equity markets during a bearish phase (Edwards \& Caglayan, 2001b), the studies of Ennis and Sebastian (2003) and Nicholas (2004) found evidence that hedge funds will outperform other markets during a bearish phase. Secondly, the empirical study will evaluate hedge fund performance in different financial environments. To accomplish this goal the three time periods were also chosen to incorporate a pre-financial crisis period, a during financial crisis period, and a post-financial crisis period, as illustrated by Figure 1.

The pre-financial crisis period (Period 1) spanned from January 2004 to December 2006, whereas the crisis period itself (Period 2) spanned from January 2007 to December 2009. The crisis period was selected to incorporate key events of the 2007 to 2009 financial crisis to ensure that the effect of the crisis can be evaluated effectively. Starting by incorporating the date when the Federal Home Loan Mortgage Corporation (Freddie Mac) announced that no more risky subprime mortgages and mortgage-related securities will be bought (27 February 2007), the takeover of Northern Rock by the UK Treasury (17 February 2008), and the announcements of Lehman Brothers Holdings Incorporated filing for bankruptcy on 15 September 2008. It also incorporates the announcement that President Obama would sign the American Recovery and Reinvestment Act of 2009, which included a variety of tax cuts and spending measures that were intended to promote economic recovery. All these events had a significant effect on global financial markets, which will make it ideal to investigate the superiority of hedge funds' investment flexibility. Finally, the post-financial crisis period stretches from January 2010 to December 2011, which will help to evaluate the performance of the US and EU hedge funds during the aftermath of the financial crisis. 




Figure 1: Sample Period Under Investigation - Illustrated by the S\&P 500 Index Source: Data were collected from Yahoo Finance (2013).

This study examines 38 prominent EU hedge funds and 84 US hedge funds. The performance of these hedge funds was estimated using monthly returns obtained from the Eurekahedge (2012) database. In order to determine whether the US or EU hedge funds outperformed associated equity markets, monthly return data were also obtained from Yahoo Finance (2012) for CAC 40, DAX, S\&P 500 and for Dow Jones. Also, the 90-day US Treasury Bill rate (constant maturity) and the Euro area bond yield were chosen as the US and EU risk-free rates, respectively. To ensure that the rankings were comparable all the ratios were calculated with both the US and EU risk-free rates for all the hedge funds and indices, respectively. The 90-day US Treasury Bill rate series was obtained from the Board of the Federal Reserve System's (2012) website and the Euro area bond yield series was obtained from the International Monetary Fund (IMF) (2012) database, respectively.

To commence with the empirical results, it is imperative to firstly evaluate the descriptive statistics of each return series. Based on the study of Amin and Kat (2003), some return distributions tend to be non-linear and nonnormally distributed, which will limit the performance ranking abilities of traditional performance ratios, like Jensen's alpha and the Sharpe ratio (Amin \& Kat, 2003). This is especially true, if the divergence from normality becomes more apparent when the higher moments (kurtosis and skewness) of the return distributions are taken into account (Kat, 2003). Furthermore, very different portfolio allocations are possible, with the presence of non-normal returns, when comparing the traditional mean-variance framework to more advanced performance measures (see for example Fung \& Hsieh, 1999a; Cvitanić, Lazrak, Martellini \& Zapatero, 2003; McFall Lamm, 2003; Terhaar, Staub \& Singer, 2003; Popova, Morton \& Popova, 2003; Wong, Phoon \& Lean, 2008). From the results reported in Table 1 , it is plausible that non-normality will be present and there is a possibility of dissimilarities between performance rankings. The results in Table 1 reveal that both the EU and US hedge fund returns are leptokurtic, except for the EU hedge funds during the post-financial crisis period that illustrated a platykurtic distribution. These results justify the findings of Fung and Hsieh (1999b), who argued that hedge fund returns are known to be leptokurtic. Also, the world indices exhibit inconsistency during all three time periods, except for the CAC 40, who display a platykurtic distribution throughout all three time periods. Furthermore, all the returns series have a negative skewness, which imply the possibility of a downside surprise (see for example McFall Lamm, 2003), except for the US hedge funds, which have a positive skewness during the post-financial crisis period. 
Table 1: Descriptive Statistics of the Returns of the Hedge Fund and World Indices

\begin{tabular}{|c|c|c|c|c|c|c|c|c|}
\hline \multicolumn{9}{|c|}{ Descriptive Statistics of Hedge Funds } \\
\hline \multirow[b]{2}{*}{ Averages } & \multicolumn{8}{|c|}{ EU Hedge Funds } \\
\hline & Mean & Median & Max. & Min. & $\begin{array}{l}\text { Std. } \\
\text { Dev. }\end{array}$ & Skewness & Kurtosis & Jarque-Bera \\
\hline Pre-financial crisis period & 0.011 & 0.013 & 0.060 & -0.046 & 0.024 & -0.315 & 3.334 & $3.498 * *$ \\
\hline During financial crisis period & 0.002 & 0.004 & 0.091 & -0.087 & 0.038 & -0.089 & 4.174 & $13.401 * *$ \\
\hline Post-financial crisis period & -0.001 & -0.002 & 0.057 & -0.069 & 0.032 & -0.152 & 2.849 & $1.240 * *$ \\
\hline \multirow[b]{2}{*}{ Averages } & \multicolumn{8}{|c|}{ US Hedge Funds } \\
\hline & Mean & Median & Max. & Min. & $\begin{array}{l}\text { Std. } \\
\text { Dev. }\end{array}$ & Skewness & Kurtosis & Jarque-Bera \\
\hline Pre-financial crisis period & 0.008 & 0.009 & 0.067 & -0.055 & 0.028 & -0.200 & 3.423 & $4.580 * *$ \\
\hline During financial crisis period & 0.004 & 0.008 & 0.111 & -0.130 & 0.050 & -0.469 & 4.160 & $11.000 * *$ \\
\hline Post-financial crisis period & 0.003 & 0.003 & 0.101 & -0.08 & 0.044 & 0.034 & 3.441 & $9.007 * *$ \\
\hline \multicolumn{9}{|c|}{ Descriptive Statistics of World Indices } \\
\hline \multirow[b]{2}{*}{ Averages } & \multicolumn{8}{|c|}{ CAC 40} \\
\hline & Mean & Median & Max. & Min. & $\begin{array}{l}\text { Std. } \\
\text { Dev. }\end{array}$ & Skewness & Kurtosis & Jarque-Bera \\
\hline Pre-financial crisis period & 0.013 & 0.017 & 0.053 & -0.05 & 0.026 & -0.590 & 2.859 & $2.117 * *$ \\
\hline During financial crisis period & -0.008 & -0.009 & 0.126 & -0.135 & 0.061 & -0.270 & 2.768 & $0.518 * *$ \\
\hline Post-financial crisis period & -0.008 & -0.013 & 0.087 & -0.113 & 0.056 & -0.015 & 1.992 & $1.018 * *$ \\
\hline \multirow[b]{2}{*}{ Averages } & \multicolumn{8}{|c|}{ DAX } \\
\hline & Mean & Median & Max. & Min. & $\begin{array}{l}\text { Std. } \\
\text { Dev. }\end{array}$ & Skewness & Kurtosis & Jarque-Bera \\
\hline Pre-financial crisis period & 0.015 & 0.023 & 0.066 & -0.053 & 0.031 & -0.443 & 2.315 & $1.880 * *$ \\
\hline During financial crisis period & 0.000 & 0.018 & 0.168 & -0.151 & 0.069 & -0.284 & 3.156 & $0.520 * *$ \\
\hline Post-financial crisis period & 0.001 & -0.001 & 0.116 & -0.192 & 0.061 & -0.899 & 5.577 & $9.875^{*}$ \\
\hline \multirow[b]{2}{*}{ Averages } & \multicolumn{8}{|c|}{ S\&P 500} \\
\hline & Mean & Median & Max. & Min. & $\begin{array}{l}\text { Std. } \\
\text { Dev. }\end{array}$ & Skewness & Kurtosis & Jarque-Bera \\
\hline Pre-financial crisis period & 0.007 & 0.011 & 0.037 & -0.036 & 0.020 & -0.443 & 2.296 & $1.921 * *$ \\
\hline During financial crisis period & -0.008 & 0.009 & 0.086 & -0.204 & 0.061 & -1.077 & 4.307 & $9.519 *$ \\
\hline Post-financial crisis period & 0.003 & -0.001 & 0.097 & -0.089 & 0.050 & -0.041 & 2.262 & $0.551 * *$ \\
\hline \multirow[b]{2}{*}{ Averages } & \multicolumn{8}{|c|}{ DOW JONES } \\
\hline & Mean & Median & Max. & Min. & $\begin{array}{l}\text { Std. } \\
\text { Dev. }\end{array}$ & Skewness & Kurtosis & Jarque-Bera \\
\hline Pre-financial crisis period & 0.005 & 0.006 & 0.038 & -0.031 & 0.021 & -0.091 & 1.853 & $2.024 * *$ \\
\hline During financial crisis period & -0.006 & 0.001 & 0.079 & -0.164 & 0.056 & -0.932 & 3.711 & $5.972 *$ \\
\hline Post-financial crisis period & 0.005 & 0.008 & 0.087 & -0.086 & 0.044 & -0.094 & 2.324 & $0.493 * *$ \\
\hline
\end{tabular}

** The null-hypothesis of a normal distribution is not rejected at a 5\% confidence level. * The null-hypothesis of a normal distribution is rejected at a $5 \%$ confidence level. ${ }^{+}$Note: All the return series are also stationary at $\mathrm{I}(0)$, with both Augmented Dickey-Fuller functions including only an intercept and a trend and intercept, respectively. Source: Compiled by authors.

From these findings it can be argued that most of the return series ought to possess a non-normal distribution profile, however based on the average Jarque-Bera estimates, all the hedge funds are normally distributed. This is, however, a misperception created by looking at the averages only; in reality several of the US and EU hedge funds exhibited a non-normal distribution when looking at the individual funds. During the prefinancial crisis period six EU hedge funds and 22 US hedge funds are not normally distributed, whereas $10 \mathrm{EU}$ hedge funds and 30 US hedge funds are not normally distributed during the crisis period. During the post-financial crisis period, this number decreased to only one EU hedge fund and thirteen US hedge funds not being normally distributed.

The DAX exhibits a non-normal distribution during the post-financial crisis period and the S\&P 500 and Dow Jones exhibit a non-normal distribution during the crisis period. The CAC 40, on the other hand, had a normal distribution throughout all three periods. Furthermore, it can be argued that although the standard deviation of all these returns is relatively low, the presence of non-normality will lead to a misperception of the actual risk present. This is due to the high kurtosis and negative skewness which will cause the variance and standard deviation to 
mimic a low overall risk, causing traditional performance measures, like the Sharpe ratio, to generate bias performance rankings (see for example Bernardo \& Ledoit, 2000; McFall Lamm, 2003). Also, with the inconsistencies between normal and non-normal distributions, these performance measures will provide different rankings, which is inconsistent with the findings of Pfingsten, Wagner and Wolferink (2004), Pedersen and Rudholm-Alfvin (2003) and of Eling and Schuhmacher (2007), who found strong correlation between their rankings. This study will, therefore, make use of the Omega ratio as the main benchmark, to determine if the presence of non-normality have influenced the rankings of each performance measure. This approach is based on the fact that the Omega ratio treats upside and downside risk differently, thus heeding the criticism of the mean-variance portfolio optimisation of Markowitz (Gilli, Schumann, Di Tollo \& Cabej, 2011, p. 95). The Omega ratio also includes information over the entire distribution encoded in the first four moments (Togher \& Barsbay, 2007); it does not require any assumptions about any moments (De Wet, Krige \& Smit, 2008); and thus no assumptions are required on the utility function of an investor (Favre-Bulle \& Pache, 2003).

The second step of the empirical study will be to determine the level of correlation between the hedge funds, where the presence of correlation can cause the Sharpe ratio to generate bias performance rankings. This is based on Sharpe (1994) who argued that the Sharpe ratio assumes that individual securities are uncorrelated with the mean portfolio return. The results of Tables $\mathrm{A}$ through $\mathrm{C}$ in the appendix exhibit the presence of a moderate correlation level between the US and EU hedge funds. Although the overall correlation is positive, a few funds display a negative average correlation throughout the three time periods under investigation. Also, a small increase in average correlation was present among the hedge funds, although most hedge funds exhibit a decrease in average correlation during the post-financial crisis period to approximately the same level as the pre-financial crisis period. These findings reported in Tables A through C, therefore, further emphasise the possibility that the Sharpe ratio will generate bias performance rankings, due to the presence of correlation between the US and EU hedge funds. This implies that these rankings must be interpreted with extreme caution and must be benchmarked with the Omega ratio to ensure a more unbiased ranking.

Table 2: The Average Correlation between Hedge Funds and Equity Markets

\begin{tabular}{|l|c|c|c|c|c|c|c|c|c|c|c|c|}
\hline & \multicolumn{4}{|c|}{ Pre-Financial Crisis Period } & \multicolumn{3}{c|}{ During Financial Crisis Period } & \multicolumn{3}{c|}{ Post-Financial Crisis Period } \\
\hline $\begin{array}{l}\text { Hedge } \\
\text { Funds }\end{array}$ & $\begin{array}{c}\text { CAC } \\
\mathbf{4 0}\end{array}$ & $\mathbf{D A X}$ & $\begin{array}{c}\text { S\&P } \\
\mathbf{5 0 0}\end{array}$ & $\begin{array}{c}\text { Dow } \\
\text { Jones }\end{array}$ & $\begin{array}{c}\text { CAC } \\
\mathbf{4 0}\end{array}$ & $\mathbf{D A X}$ & $\begin{array}{c}\text { S\&P } \\
\mathbf{5 0 0}\end{array}$ & $\begin{array}{c}\text { Dow } \\
\text { Jones }\end{array}$ & $\begin{array}{c}\text { CAC } \\
\mathbf{4 0}\end{array}$ & DAX & $\begin{array}{c}\text { S\&P } \\
\mathbf{5 0 0}\end{array}$ & $\begin{array}{c}\text { Dow } \\
\text { Jones }\end{array}$ \\
\hline EU & 0.577 & 0.533 & 0.408 & 0.340 & 0.554 & 0.524 & 0.493 & 0.444 & 0.481 & 0.461 & 0.509 & 0.488 \\
\hline US & 0.389 & 0.428 & 0.498 & 0.407 & 0.571 & 0.576 & 0.572 & 0.510 & 0.608 & 0.562 & 0.689 & 0.667 \\
\hline
\end{tabular}

Source: Compiled by authors.

The results in Table 2 indicate that most EU hedge funds showed a relative constant average correlation with the different world equity markets, with an increase in this correlation over the three time periods. This illustrates a higher dependence on equities, especially with the S\&P 500 and Dow Jones. Although it was to be expected that the average correlation should increase during the financial crisis period and stabilise afterwards, the results displayed a continuation in this trend.

The US and EU hedge funds also exhibit a higher level of average correlation between S\&P 500 and Dow Jones during the post-financial crisis period, which may be due to a lower level of anticipated risk (volatility) in these markets. These results do, therefore, not conclusively prove that US and EU hedge funds are more correlated with equity markets during bullish or bearish phases, which contradict the results found by Edwards and Caglayan (2001b). This implies that hedge funds may still have the ability to outperform equity markets during both a bearish and/or bullish phase, which will be established by the results found with the estimation of the different performance measures later on (see Tables 4 and 6). 
Table 3: The Level of Volatility between the Hedge Funds and Equity Markets

\begin{tabular}{|l|c|c|c|}
\hline \multicolumn{3}{|c|}{ Percentage of Hedge Funds Under the Top 10 Ranking for Highest Volatility } \\
\hline & Pre-Crisis Period & During Crisis Period & Post-Crisis Period \\
\hline EU Hedge Funds & $20 \%$ & $0 \%$ & $0 \%$ \\
\hline US Hedge Funds & $80 \%$ & $100 \%$ & $100 \%$ \\
\hline \multicolumn{2}{|c|}{ Ranking of Indices: A Ranking Closer to One is Associated with a Higher Level of Volatility (Risk) } \\
\hline \multicolumn{2}{|c|}{ Pre-Crisis Period } & During Crisis Period & Post-Crisis Period \\
\hline DAC 40 & 53 & 25 & 11 \\
\hline S\&P 500 & 35 & 18 & 41 \\
\hline Dow Jones & 92 & 29 & 55 \\
\hline
\end{tabular}

${ }^{+}$Note that the upper part of this table provides a summary of how many of the 84 US hedge funds, the 38 EU hedge funds and 4 world indices (a total of 126) ranked under the top 10 best performing entities. The bottom part of this table illustrates the rankings of the different equity indices from a total of 126, respectively. Source: Compiled by authors.

The third step of the empirical study will be to determine the level of volatility over the three different financial environment periods, which will be determined by estimating an Exponential Weighted Moving Average (EWMA) model. From Table 3 it is evident that US hedge funds exhibit the highest volatility level throughout all three time periods, based on the top 10 rankings. This implies that some US hedge funds consist of a higher level of risk compared to EU hedge funds, not only during the financial crisis period but also before and after the crisis period. These results accentuate the findings of Ackermann, McEnally and Ravenscraft (1999), where hedge funds were associated with higher volatility levels compared to market indices. Further results also display that the volatility level increased in the equity markets as well, and continued to increase in the CAC 40 and DAX even after the financial crisis, but decreased in the S\&P 500 and Dow Jones. This emphasise the results found in Table 2, where US and EU hedge funds were more correlated with the S\&P 500 and Dow Jones during the post-financial crisis period. These results, therefore, justify the fact that the S\&P 500 and Dow Jones may have been associated as markets with a lesser degree of anticipated risk (volatility), making them more desirable during times where markets will exhibit extreme noise.

The fourth step of this empirical study is to determine if US or EU hedge funds were the more dominant funds over the three time periods, by means of the Sharpe, Sortino, Treynor, Jensen's alpha, Calmar and Omega ratios, respectively. In order to provide a more composite report, the following tables will report the percentage of the US and EU hedge funds that were ranked under the top 10 (best 10 performing hedge funds/equity markets). By doing so a more comprehensive conclusion can be made, regarding which hedge funds were the more dominant performers over the three periods. From the results reported in Table 4 it can be argued, based on the Sharpe, Sortino, Calmar and Omega ratio, that more US hedge funds were ranked under the top 10 best performing entities during the pre-financial crisis period. The one exception occurs where the Sharpe ratio (using the EU risk-free rate), emphasise the performance of the EU hedge funds. Even so, this dominance of the US hedge funds may be explained by the fact that US hedge funds were more volatile, based on the results from Tables 2 and 3 . These results are also corroborated by the results reported in Table 5. It is clear that US hedge funds were able to generate a higher level of average cumulative returns during the crisis period and post-financial crisis periods. The EU hedge funds display a higher level of average cumulative returns during the pre-financial crisis period though (see Table 5), which is consistent with the results found by the Sharpe ratio in Table 4.

The results are, however, inconclusive during the crisis period, where the Sharpe and Omega ratios reported that EU hedge funds were more dominant under the top 10 rankings, while the Sortino ratio indicates that the US hedge funds are dominant. Although Omega and Sortino differ in terms of the top ranked hedge funds, they still rank hedge funds over the stock market indices. These findings contradict the findings of Duong (2008), who found that hedge funds tend to underperform equity markets when accounting for downside risk with the use of the Sortino and Omega ratios. The US and EU hedge funds also exhibit a similar performance during the crisis period based on the Calmar ratio's rankings.

The results for the post-financial crisis period are slightly different in that all the performance ratios reported that the US hedge funds were more dominant during the post-financial crisis period. This weaker performance of the EU hedge funds can partly be explained by the start of the European sovereign debt crisis in late 
2009. This period saw a number of downgrades of government debt and rising government and private debt levels in some European states, therefore, decreasing investors' confidence in EU investments.

When assessing the overall picture it is evident that several US and EU hedge funds were able to outperform the equity markets during all three time periods. This was confirmed by all the performance measures. However, not all the measures placed the same funds in the same positions, a fact that can greatly be ascribed to the presence of non-normality in the return distributions. That is why the traditional performance measures, like the Sharpe ratio, should be benchmarked with the Omega ratio to overcome its shortcomings. Overall, these results contradict the results found by Ackermann, McEnally and Ravenscraft (1999) and Brown, Goetzmann and Ibbotson (1999). The results does, however, corroborate the results of Edwards and Caglayan (2001a), who reported that hedge funds tend to outperform equity markets in terms of traditional performance ratios, like the Sharpe ratio. 
Table 4: Performance Evaluation

\begin{tabular}{|c|c|c|c|c|c|c|c|}
\hline \multicolumn{8}{|c|}{ Sharpe Ratio } \\
\hline \multicolumn{4}{|c|}{ Making Use of the EU Risk-Free Rate } & \multicolumn{4}{|c|}{ Making Use of the US Risk-Free Rate } \\
\hline \multicolumn{4}{|c|}{ Percentage of Hedge Funds Under the Top 10} & \multicolumn{4}{|c|}{ Percentage of Hedge Funds Under the Top 10} \\
\hline & Pre-Crisis Period & During Crisis Period & Post-Crisis Period & & Pre-Crisis Period & During Crisis Period & Post-Crisis Period \\
\hline EU Hedge Funds & $50 \%$ & $60 \%$ & $30 \%$ & EU Hedge Funds & $40 \%$ & $60 \%$ & $30 \%$ \\
\hline US Hedge Funds & $50 \%$ & $40 \%$ & $70 \%$ & US Hedge Funds & $60 \%$ & $40 \%$ & $70 \%$ \\
\hline \multicolumn{4}{|c|}{ Ranking of Indices Where One is the Most Superior } & \multicolumn{4}{|c|}{ Ranking of Indices Where One is the Most Superior } \\
\hline & Pre-Crisis Period & During Crisis Period & Post-Crisis Period & & Pre-Crisis Period & During Crisis Period & Post-Crisis Period \\
\hline CAC 40 & 39 & 116 & 96 & CAC 40 & 38 & 119 & 103 \\
\hline$\overline{\mathrm{DAX}}$ & 38 & 82 & 63 & DAX & 39 & 90 & 75 \\
\hline S\&P 500 & 72 & 118 & 49 & S\&P 500 & 74 & 122 & 61 \\
\hline Dow Jones & 110 & 115 & 38 & Dow Jones & 107 & 117 & 44 \\
\hline \multicolumn{8}{|c|}{ Sortino Ratio } \\
\hline \multirow{2}{*}{\multicolumn{4}{|c|}{$\begin{array}{l}\text { Using the EU Risk-Free Rate as Target Rate } \\
\text { Percentage of Hedge Funds Under the Top } 10\end{array}$}} & \multirow{2}{*}{\multicolumn{4}{|c|}{$\begin{array}{l}\text { Using the US Risk-Free Rate as Target Rate } \\
\text { Percentage of Hedge Funds Under the Ton } 10\end{array}$}} \\
\hline & & & & & & & \\
\hline & Pre-Crisis Period & During Crisis Period & Post-Crisis Period & & Pre-Crisis Period & During Crisis Period & Post-Crisis Period \\
\hline EU Hedge Funds & $40 \%$ & $40 \%$ & $30 \%$ & EU Hedge Funds & $40 \%$ & $40 \%$ & $30 \%$ \\
\hline US Hedge Funds & $60 \%$ & $60 \%$ & $70 \%$ & US Hedge Funds & $60 \%$ & $60 \%$ & $70 \%$ \\
\hline \multicolumn{4}{|c|}{ Ranking of Indices Where One is the Most Superior } & \multicolumn{4}{|c|}{ Ranking of Indices Where One is the Most Superior } \\
\hline & Pre-Crisis Period & During Crisis Period & Post-Crisis Period & & Pre-Crisis Period & During Crisis Period & Post-Crisis Period \\
\hline CAC 40 & 44 & 117 & 96 & CAC 40 & 57 & 124 & 109 \\
\hline DAX & 39 & 82 & 60 & DAX & 58 & 97 & 75 \\
\hline S\&P 500 & 77 & 112 & 48 & S\&P 500 & 76 & 118 & 60 \\
\hline Dow Jones & 108 & 109 & 38 & Dow Jones & 111 & 125 & 48 \\
\hline \multicolumn{8}{|c|}{ Omega Ratio } \\
\hline \multicolumn{4}{|c|}{ Using the EU Risk-Free Rate as the Threshold } & \multirow{2}{*}{\multicolumn{4}{|c|}{$\begin{array}{l}\text { Using the US Risk-Free Rate as the Threshold } \\
\text { Percentage of Hedge Funds Under the Top } 10\end{array}$}} \\
\hline \multicolumn{4}{|c|}{ Percentage of Hedge Funds Under the Top 10} & & & & \\
\hline & Pre-Crisis Period & During Crisis Period & Post-Crisis Period & & Pre-Crisis Period & Percentage of Hedge Funds Under the Top 10 & Post-Crisis Period \\
\hline EU Hedge Funds & $30 \%$ & $60 \%$ & $30 \%$ & EU Hedge Funds & $30 \%$ & $60 \%$ & $30 \%$ \\
\hline US Hedge Funds & $70 \%$ & $40 \%$ & $70 \%$ & US Hedge Funds & $70 \%$ & $40 \%$ & $70 \%$ \\
\hline \multicolumn{4}{|c|}{ Ranking of Indices Where One is the Most Superior } & \multicolumn{4}{|c|}{ Ranking of Indices Where One is the Most Superior } \\
\hline & Pre-Crisis Period & During Crisis Period & Post-Crisis Period & & Pre-Crisis Period & During Crisis Period & Post-Crisis Period \\
\hline CAC 40 & 46 & 120 & 99 & CAC 40 & 48 & 118 & 99 \\
\hline$\overline{\mathrm{DAX}}$ & 54 & 91 & 73 & DAX & 54 & 93 & 74 \\
\hline S\&P 500 & 78 & 122 & 61 & S\&P 500 & 78 & 122 & 61 \\
\hline Dow Jones & 107 & 119 & 44 & Dow Jones & 105 & 119 & 44 \\
\hline \multicolumn{4}{|c|}{ CALMAR RATIO } & & & & \\
\hline \multicolumn{4}{|c|}{ Percentage of Hedge Funds Under the Top 10} & & & & \\
\hline & Pre-Crisis Period & During Crisis Period & Post-Crisis Period & & & & \\
\hline EU Hedge Funds & $40 \%$ & $50 \%$ & $30 \%$ & & & & \\
\hline US Hedge Funds & $60 \%$ & $50 \%$ & $70 \%$ & & & & \\
\hline \multicolumn{4}{|c|}{ Ranking of Indices Where One is the Most Superior } & & & & \\
\hline & Pre-Crisis Period & During Crisis Period & Post-Crisis Period & & & & \\
\hline CAC 40 & 45 & 120 & 103 & & & & \\
\hline DAX & 21 & 93 & 75 & & & & \\
\hline S\&P 500 & 67 & 118 & 61 & & & & \\
\hline Dow Jones & 91 & 115 & 43 & & & & \\
\hline
\end{tabular}

Note that the upper part of the table of each performance measure provides a summary of how many of the 84 US hedge funds, the 38 EU hedge funds, and 4 world indices
ntities. The bottom part of each performance measure illustrates the rankings of the different equity indices from a total of 126, respectively. Source: Compiled by authors.

Copyright by author(s); CC-BY 
Table 5: The Average Cumulative Returns of the Different Hedge Funds

\begin{tabular}{|l|c|c|c|}
\hline & Pre-Crisis Period & During Crisis Period & Post-Crisis Period \\
\hline EU Hedge Funds & $14.31 \%$ & $1.85 \%$ & $-1.43 \%$ \\
\hline US Hedge Funds & $10.14 \%$ & $3.52 \%$ & $3.00 \%$ \\
\hline
\end{tabular}

Source: Compiled by authors.

Table 6: Outperformance Evaluation

\begin{tabular}{|c|c|c|c|c|c|c|c|}
\hline \multicolumn{8}{|c|}{ Sortino Ratio } \\
\hline \multicolumn{4}{|c|}{ Making Use of the CAC 40 as the Target Rate } & \multicolumn{4}{|c|}{ Making Use of the DAX As the Target Rate } \\
\hline \multicolumn{4}{|c|}{ Percentage of Hedge Funds Under the Top 10} & \multicolumn{4}{|c|}{ Percentage of Hedge Funds Under the Top 10} \\
\hline & $\begin{array}{l}\text { Pre-Crisis } \\
\text { Period }\end{array}$ & $\begin{array}{c}\text { During Crisis } \\
\text { Period }\end{array}$ & $\begin{array}{c}\text { Post-Crisis } \\
\text { Period }\end{array}$ & & $\begin{array}{l}\text { Pre-Crisis } \\
\text { Period }\end{array}$ & $\begin{array}{c}\text { During } \\
\text { Crisis } \\
\text { Period }\end{array}$ & $\begin{array}{l}\text { Post-Crisis } \\
\text { Period }\end{array}$ \\
\hline $\begin{array}{l}\text { Eu Hedge } \\
\text { Funds }\end{array}$ & $60 \%$ & $40 \%$ & $20 \%$ & $\begin{array}{l}\text { Eu Hedge } \\
\text { Funds }\end{array}$ & $60 \%$ & $50 \%$ & $30 \%$ \\
\hline $\begin{array}{l}\text { Us Hedge } \\
\text { Funds }\end{array}$ & $40 \%$ & $60 \%$ & $80 \%$ & $\begin{array}{l}\text { Us Hedge } \\
\text { Funds }\end{array}$ & $40 \%$ & $50 \%$ & $70 \%$ \\
\hline \multicolumn{8}{|c|}{ Treynor Ratio } \\
\hline \multicolumn{4}{|c|}{ Using the CAC 40 as the Market Portfolio } & \multicolumn{4}{|c|}{ Using the DAX as the Market Portfolio } \\
\hline \multicolumn{4}{|c|}{ Percentage of Hedge Funds Under the Top 10} & \multicolumn{4}{|c|}{ Percentage of Hedge Funds Under the Top 10} \\
\hline & $\begin{array}{c}\text { Pre-Crisis } \\
\text { Period }\end{array}$ & $\begin{array}{c}\text { During Crisis } \\
\text { Period }\end{array}$ & $\begin{array}{c}\text { Post-Crisis } \\
\text { Period }\end{array}$ & & $\begin{array}{l}\text { Pre-Crisis } \\
\text { Period }\end{array}$ & $\begin{array}{c}\text { During Crisis } \\
\text { Period }\end{array}$ & $\begin{array}{c}\text { Post-Crisis } \\
\text { Period }\end{array}$ \\
\hline $\begin{array}{l}\text { Eu Hedge } \\
\text { Funds }\end{array}$ & $10 \%$ & $10 \%$ & $30 \%$ & $\begin{array}{l}\text { Eu Hedge } \\
\text { Funds }\end{array}$ & $20 \%$ & $20 \%$ & $30 \%$ \\
\hline $\begin{array}{l}\text { Us Hedge } \\
\text { Funds }\end{array}$ & $90 \%$ & $90 \%$ & $70 \%$ & $\begin{array}{l}\text { Us Hedge } \\
\text { Funds }\end{array}$ & $80 \%$ & $80 \%$ & $70 \%$ \\
\hline \multicolumn{4}{|c|}{$\begin{array}{l}\text { Using the S\&P } 500 \text { as the Market Portfolio } \\
\end{array}$} & \multicolumn{4}{|c|}{ Using the Dow Jones as the Market Portfolio } \\
\hline \multicolumn{4}{|c|}{ Percentage of Hedge Funds Under the Top 10} & \multicolumn{4}{|c|}{ Percentage of Hedge Funds Under the Top 10} \\
\hline & $\begin{array}{l}\text { Pre-Crisis } \\
\text { Period }\end{array}$ & $\begin{array}{c}\text { During Crisis } \\
\text { Period }\end{array}$ & $\begin{array}{l}\text { Post-Crisis } \\
\text { Period }\end{array}$ & & $\begin{array}{l}\text { Pre-Crisis } \\
\text { Period }\end{array}$ & $\begin{array}{c}\text { During Crisis } \\
\text { Period }\end{array}$ & $\begin{array}{l}\text { Post-Crisis } \\
\text { Period }\end{array}$ \\
\hline $\begin{array}{l}\text { Eu Hedge } \\
\text { Funds }\end{array}$ & $40 \%$ & $20 \%$ & $20 \%$ & $\begin{array}{l}\text { Eu Hedge } \\
\text { Funds }\end{array}$ & $40 \%$ & $30 \%$ & $20 \%$ \\
\hline $\begin{array}{l}\text { Us Hedge } \\
\text { Funds }\end{array}$ & $60 \%$ & $80 \%$ & $80 \%$ & $\begin{array}{l}\text { Us Hedge } \\
\text { Funds }\end{array}$ & $60 \%$ & $70 \%$ & $80 \%$ \\
\hline \multicolumn{8}{|c|}{ Jensen's Alpha } \\
\hline \multicolumn{4}{|c|}{ Using the CAC 40 as the Market Portfolio } & \multicolumn{4}{|c|}{ Using the DAX as the Market Portfolio } \\
\hline \multicolumn{4}{|c|}{ Percentage of Hedge Funds Under the Top 10} & \multicolumn{4}{|c|}{ Percentage of Hedge Funds Under the Top 10} \\
\hline & $\begin{array}{l}\text { Pre-Crisis } \\
\text { Period }\end{array}$ & $\begin{array}{c}\text { During Crisis } \\
\text { Period }\end{array}$ & $\begin{array}{l}\text { Post-Crisis } \\
\text { Period }\end{array}$ & & $\begin{array}{l}\text { Pre-Crisis } \\
\text { Period }\end{array}$ & $\begin{array}{l}\text { During Crisis } \\
\text { Period }\end{array}$ & $\begin{array}{l}\text { Post-Crisis } \\
\text { Period }\end{array}$ \\
\hline $\begin{array}{l}\text { Eu Hedge } \\
\text { Funds }\end{array}$ & $80 \%$ & $40 \%$ & $30 \%$ & $\begin{array}{l}\text { Eu Hedge } \\
\text { Funds }\end{array}$ & $80 \%$ & $60 \%$ & $40 \%$ \\
\hline $\begin{array}{l}\text { Us Hedge } \\
\text { Funds }\end{array}$ & $20 \%$ & $60 \%$ & $70 \%$ & $\begin{array}{l}\text { Us Hedge } \\
\text { Funds }\end{array}$ & $20 \%$ & $40 \%$ & $60 \%$ \\
\hline \multicolumn{4}{|c|}{ Using the S\&P 500 as the Market Portfolio } & \multicolumn{4}{|c|}{ Using the Dow Jones as the Market Portfolio } \\
\hline \multicolumn{4}{|c|}{ Percentage of Hedge Funds Under the Top 10} & \multicolumn{4}{|c|}{ Percentage of Hedge Funds Under the Top 10} \\
\hline & $\begin{array}{c}\text { Pre-Crisis } \\
\text { Period }\end{array}$ & $\begin{array}{c}\text { During Crisis } \\
\text { Period }\end{array}$ & $\begin{array}{c}\text { Post-Crisis } \\
\text { Period } \\
\end{array}$ & & $\begin{array}{l}\text { Pre-Crisis } \\
\text { Period } \\
\end{array}$ & $\begin{array}{c}\text { During Crisis } \\
\text { Period } \\
\end{array}$ & $\begin{array}{c}\text { Post-Crisis } \\
\text { Period } \\
\end{array}$ \\
\hline $\begin{array}{l}\text { Eu Hedge } \\
\text { Funds }\end{array}$ & $10 \%$ & $50 \%$ & $50 \%$ & $\begin{array}{l}\text { Eu Hedge } \\
\text { Funds }\end{array}$ & $10 \%$ & $60 \%$ & $60 \%$ \\
\hline $\begin{array}{l}\text { Us Hedge } \\
\text { Funds }\end{array}$ & $90 \%$ & $50 \%$ & $50 \%$ & $\begin{array}{l}\text { Us Hedge } \\
\text { Funds }\end{array}$ & $90 \%$ & $40 \%$ & $40 \%$ \\
\hline
\end{tabular}

${ }^{+}$Note that the upper part of the table of each performance measure provides a summary of how many of the 84 US hedge funds, the 38 EU hedge funds, and 4 world indices (a total of 126) ranked under the top 10 entities. Source: Compiled by authors.

In order to check the robustness of the results, in terms of the presence of outperformance, the Sortino ratio was estimated with the CAC 40 and DAX as target rates, respectively. This approach was also followed in the estimation of the Treynor ratio and the Jensen's alpha, where all four equity markets were used as the market 
portfolio, respectively. The results from Table 6 emphasise that several US and EU hedge funds were able to outperform the equity markets during all three time periods. Based on the results of the Sortino ratio, EU hedge funds were able to outperform the CAC 40 and the DAX more frequently than US hedge funds could during the prefinancial crisis period. Several EU hedge funds also outperformed the DAX during the crisis period. These results were also confirmed by Jensen's alpha, reporting that EU hedge funds outperformed the CAC 40 more often than the US hedge funds during the pre-financial crisis period and outperformed the DAX more often than the US hedge funds during the pre-crisis and crisis periods. However, Jensen's alpha also reported similar performance for both US and EU hedge funds, where they exhibit similar performance in outperforming the S\&P 500 during the crisis and post-financial crisis periods. Evidence from Table 6 further shows that EU hedge funds were able to outperform the Dow Jones more often than US hedge funds during the crisis and post-financial crisis periods.

From the remaining results reported by the Sortino ratio and Jensen's alpha, it is confirmed that US hedge funds were able to outperform the CAC 40 and the DAX more often than EU hedge funds. These findings were further stressed by the results of the Treynor ratio, where the US hedge funds exhibit greater incidence of outperforming all the equity markets during all three time periods than EU hedge funds did. From these results it is conclusive that although US hedge funds exhibited a higher level of volatility throughout the three time periods, they were also more likely to illustrate greater overall performance than EU hedge funds and equity markets. The results from Table 6 also illustrates that hedge funds were able to outperform their associated equity markets during both a bearish and bullish phase. The results from this study, therefore, emphasise the ability of hedge funds to use its investment flexibility during different financial environments to outperform equity markets, thus making hedge funds the more superior investment vehicle.

\section{CONCLUSION AND RECOMMENDATIONS}

Conflicting evidence regarding the performance of hedge funds and their persistence in outperforming other markets have been debated by a number of previous studies. Generally, it is assumed that due to the flexibility of hedge funds, in being able to apply different investment strategies, will make them the more considered unconventional asset choice. However, previous research seems to suggest that hedge funds tend to be correlated with equity markets, implying the possibility of hedge funds underperforming during bearish phases. The relatively high attrition rate among hedge funds coupled with their non-normally distributed returns (exhibiting high kurtosis and negative skewness), makes it also difficult to provide a detailed performance evaluation of all the hedge funds.

Since non-normal distributions were also present in this study, all risk-adjusted performance results were benchmarked to the Omega ratio, in an attempt to overcome most of the shortcomings of traditional performance measures. From the results if was evident that several US and EU hedge funds were able to outperform the CAC 40, the DAX, the S\&P 500, and the Dow Jones during both a bearish and bullish phase. Also, although the US hedge funds illustrated greater volatility compared to EU hedged funds, evidence from the risk-adjusted performance measures supported the overall dominance of US hedge funds. These findings further emphasised that a normal buyand-hold strategy on the four world equity indices under investigation, would have been overshadowed by the performance of the US and EU hedge funds despite a higher correlation between the hedge funds and the Dow Jones and S\&P 500 after the financial crisis period.

These results pose a number of further questions. The first is whether different data frequencies will render different results. It would also be interesting to look at the level of cost and resource allocation efficiency of hedge funds when compared to other investment vehicles. Further research is also required on US and EU hedge funds' ability to time the market. It would also be interesting to draw a risk-weighted returns comparison between these hedge funds and mutual funds, since mutual funds are often viewed as 'safe' investment vehicles.

\section{AUTHOR INFORMATION}

Chris van Heerden, North West University, South Africa; Postal address: 11 Hoffman Street, Internal box 593, Building E3, Office 134, Potchefstroom Campus, North West University, 2531. After completing his Masters in finance in 2007, Chris van Heerden was appointed as lecturer at the School of Economics, Potchefstroom Campus, North West University. Soon after he completed his PhD in finance in 2011, he was promoted to senior lecturer and is currently Program Head of Economics. E-mail: chris.vanheerden@nwu.ac.za (Corresponding author) 
André Heymans, North West University, South Africa. After completing his $\mathrm{PhD}$ in finance in 2007, André Heymans moved to London where he was employed by BNY MELLON until the middle of 2008. He then moved to South Africa to fill the position of Head: Research and Development in the trading room at an agricultural trading firm (Free State Maize). André moved back to academia in April 2009 where he currently holds the position Program Head of Finance. E-mail: andre.heymans@nwu.ac.za

Gary van Vuuren, North West University, South Africa. Gary van Vuuren began his career with a Masters in astrophysics and $\mathrm{PhD}$ in nuclear physics. After a short time at Goldman Sachs in London, he obtained his Masters in market risk and $\mathrm{PhD}$ in credit risk and then worked as a risk manager for large South African retail banks and asset managers. He then moved to London where he was employed as a risk manager for several retail and investment banks before settling on risk assessment and regulatory compliance in financial institutions for Fitch Ratings where he remains employed. He is an accredited GARP Financial Risk Manager. E-mail: vvgary@ hotmail.com

Wilmé Brand, North West University, South Africa. After completing her Honours in finance at the North West University (Potchefstroom Campus) in 2012, Wilmé Brand is in the process of completing her Masters in finance at the Vaal Triangle Campus. The topic of this paper is a product of the work done in her Masters. E-mail: wilme.brand@nwu.ac.za

\section{REFERENCES}

1. Ackermann, C., McEnally, R., \& Ravenscraft, D. (1999). The performance of hedge funds: Risk, return, and incentives. Journal of Finance, 54(3), 833-874.

2. Agarwal, V., Daniel, N., \& Naik, N. Y. (2009). Role of managerial incentives and discretion in Hedge Fund performance. Journal of Finance, 64(5), 2221-2256.

3. Agarwal, V., \& Naik, N. Y. (2000). Multi-period performance persistence analysis of hedge funds. Journal of Financial and Quantitative Analysis, 35(3), 327-342.

4. Al-Sharkas, A. A. (2005). The return in hedge fund strategies. International Journal of Business, 10(3), 217-230.

5. Amin, G. S., \& Kat, H. M. (2003). Hedge fund performance 1990-2000: Do the "money machines" really add value? Journal of Financial and Quantitative Analysis, 38(2), 251-274.

6. Aragon, G. O. (2007). Share restrictions and asset pricing: Evidence from the hedge fund industry. Journal of Financial Economics, 83, 33-58.

7. Auer, B .R., \& Schuhmacher, F. (2013). Robust evidence on the similarity of Sharpe ratio and drawdownbased hedge fund performance rankings. Journal of International Financial Markets, Institutions and Money, 24, 153-165.

8. Bailey, D. H., \& López de Prado, M. M. (2012). The Sharpe ratio efficient frontier. Journal of Risk, 15(2), $1-45$.

9. Bernardo, A. E., \& Ledoit, O. (2000). Gain, loss and asset pricing. Journal of Political Economy, 108(1), 144-172.

10. Bertrand, P., \& Prigent, J. (2011). Omega performance measure and portfolio insurance. Journal of Banking and Finance, 35, 1811-1823.

11. Board of the Federal Reserve System. (2012). Supplier of data. Retrieved from http://www.federalreserve.gov/releases/h15/data.htm

12. Brooks, C., \& Kat, H. M. (2002). The statistical properties of hedge fund index returns and their implications for investors. The Journal of Alternative Investments, 5(2), 26-44.

13. Brown, S. J., Goetzmann, W., \& Ibbotson, R. G. (1999). Offshore hedge funds: Survival and performance, 1989-95. Journal of Business, 72(1), 91-117.

14. Capocci, D., Corhay, A., \& Hübner, G. (2005). Hedge fund performance and persistence in bull and bear markets. The European Journal of Finance, 11(5), 361-392.

15. Cvitanić, J., Lazrak, A., Martellini, L., \& Zapatero, F. (2003). Optimal allocation to hedge funds: An empirical analysis. Quantitative finance, 3(1), 28-39.

16. Deb, S. G. (2012). Value versus growth: Evidence from India. The IUP Journal of Applied Finance, 18(2), 48-62. 
17. De Wet, R., Krige, J. D., \& Smit, E. vd M. (2008). An investigation into performance rankings of the Omega ratio vs. the Sharpe ratio applied to South African general equity unit trusts. Journal of Studies in Economics and Econometrics, 32(2), 69-83

18. Duong, H. (2008). Performance of funds of hedge funds. Doctors: Old Dominion University. 113p.

19. Edwards, F. R., \& Caglayan, M. O. (2001a). Hedge fund performance and manger skill. Journal of Futures Markets, 21(11), 1003-1028.

20. Edwards, F. R., \& Caglayan, M. O. (2001b). Hedge fund and commodity fund investments in bull and bear markets. Journal of Portfolio Management, 27(4), 97-108.

21. Eling, M. (2008). Does the measure matter in the Mutual fund industry? Financial Analysts Journal, 64(3), 54-66.

22. Eling, M., \& Schuhmacher, F. (2007). Does the choice of performance measure influence the evaluation of Hedge funds? Journal of Banking and Finance, 31(9), 3-56.

23. Ennis, R. M., \& Sebastian, M. D. (2003). A critical look at the case of hedge funds. Journal of Portfolio Management, 29(4), 103-112.

24. Eurekahedge. (2012). Supplier of hedge fund data.

25. Favre-Bulle, A., \& Pache, S. (2003). The Omega measure: Hedge fund portfolio optimization. Retrieved from http://www.edge-fund.com/FBPa03.pdf

26. Fung, W., \& Hsieh, D. A. (1997). Empirical characteristics of dynamic trading strategies: The case of hedge funds. The Review of Financial Studies, 10(2), 275-302.

27. Fung, W., \& Hsieh, D. A. (1999a). Is mean-variance analysis applicable to hedge funds? Economic Letters, $62(1), 53-58$.

28. Fung, W., \& Hsieh, D. A. (1999b). A primer on hedge funds. Journal of Empirical Finance, 6(3), $309-331$.

29. Fung, W., \& Hsieh, D. A. (2004). Extracting portable alphas from equity long/short hedge funds. Journal of Investment Management, 2(4), 1-19.

30. Giamouridis, D., \& Vrontos, I. D. (2007). Hedge fund portfolio construction: A comparison of static and dynamic approaches. Journal of Banking and Finance, 31(1), 199-217.

31. Gilli, M., Schumann, E., Di Tollo, G., \& Cabej, G. (2011). Constructing 130/30-portfolios with the Omega ratio. Journal of Asset Management, 12(2), 94-108.

32. Gregoriou, G. N., \& Rouah, F. (2002). Large versus small Hedge Funds: Does size affect performance? The Journal of Alternative Investments, 5(3), 75-77.

33. International Monetary Fund (IMF). (2012). Retrieved from http://www.imf.org/external/data.htm

34. Jensen, M. C. (1968). The performance of mutual funds in the period 1945-1964. Journal of Finance, 23(2), 389-416.

35. J.P. Morgan/Reuters. (1996). RiskMetrics ${ }^{T M}-$ Technical Document (4 ${ }^{\text {th }}$ ed.). Retrieved from http://gloriamundi.com/UploadFile/2010-2/rmtd.pdf

36. Kanellakos, J. P. (2005). Hedge fund risk-adjusted performance measures: A critical review (p. 134). Masters: Dalhousie University.

37. Kat, H. M. (2003). 10 Things investors should know about hedge funds. The Journal of Wealth Management, 5(4), 72-81.

38. Kosowski, R., Naik, N. Y., \& Teo, M. (2007). Do hedge funds deliver alpha? A Bayesian and bootstrap analysis. Journal of Financial Economics, 84(1), 229-264.

39. Lamm, R. M. (1999). Portfolio of alternative assets: Why not 100\% hedge funds? The Journal of Investing, 8(40), 87-97.

40. Lamm, R. M. (2003). Asymmetric returns and optimal hedge fund portfolios. Journal of Alternative Investments, 6(2), 9-21.

41. Lavino, S. (2000). The hedge fund handbook: A definitive guide to analyzing and evaluating alternative investments. New York: McGraw-Hill.

42. Li, Y. (2006). Three assays on hedge funds characteristics, performance, risk and managerial incentives (p. 157). Doctors: University of Massachusetts Amherst.

43. Liang, B. (1999). On the performance of hedge funds. Financial Analysts Journal, 55(4), 72-85.

44. Liang, B. (2000). Hedge funds: The living and the dead. Journal of Financial and Quantitative Analysis, 35(3), 309-326.

45. Lo, A. W. (2001). Risk management for hedge funds: Introduction and overview. Financial Analysts Journal, 57(6), 16-33. 
46. Lo, A. W. (2002). The statistics of Sharpe ratios. Financial Analysts Journal, 58(4), 36-52.

47. McCarthy, D., \& Spurgin, R. (1998). A comparison of return patterns in traditional and alternative investments. In S. Jaffer, (ed.). Alternative investment strategies. London: Euromaony Books in Association with AIMA.

48. McFall Lamm, R. (2003). Asymmetric returns and optimal hedge fund portfolios. Journal of Alternative Investments, 6(2), 9-21.

49. National Treasury. (2012). The Regulation of hedge funds in South Africa: A proposed framework issued by the National Treasury and Financial Service Board. Retrieved from http://www.treasury.gov.za/comm_media/press/2012/ANNEXURE\%20A\%20-

Regulation\%20of\%20Hedge\%20Funds\%20in\%20South\%20Africa-\%20A\%20proposed\%20framework\%

50. 20\%20September\%202012.pdf

51. Nicholas, J. G. (2004). Hedge fund of funds investing: An investor's guide. Princeton: Bloomberg Press.

52. Pedersen, C. S., \& Rudholm-Alfvin, T. (2003). Selecting a risk-adjusted shareholder performance measure. Journal of Asset Management, 4(3), 152-172.

53. Pfingsten, A., Wagner, P., \& Wolferink, C. (2004). An empirical investigation of the rank correlation between different risk measures. Journal of Risk, 6(4), 55-74.

54. Popova, I., Morton, D., \& Popova, E. (2003). Optimal hedge fund allocation with asymmetric preferences and distributions (p. 25). New York: Global research center, Deutsche asset management.

55. Sedzro, K. (2009). New evidence on hedge fund performance measures. International Business and Economics Research Journal, 8(11), 95-106.

56. Sharpe, W. F. (1966). Mutual fund performance. Journal of Business, 39(1), 119-138.

57. Sharpe, F. A. (1994). The Sharpe ratio. Journal of Portfolio Management, 21(1), 49-58.

58. Schneeweis, T., Kazemi, H., \& Martin, G. (2001). Understanding hedge fund performance: Research results and rules of thumb for the institutional investor. Lehman Brothers. Retrieved from http://www.edge-fund.com/ScKM01.pdf

59. Schneeweis, T., \& Spurgin, R. (1998). Multifactor analysis of hedge fund, managed futures and mutual fund return and risk characteristics. The Journal of Alternative Investments, 1(2), 1-24.

60. Schuster, M., \& Auer, B. R. (2012). A note on empirical Sharpe ratio dynamics. Economics Letters, 116, 124-128.

61. Shadwick, W. F., \& Keating, C. (2002). A universal performance measure. Journal of Performance Measurement, 6(3), 59-84.

62. Shin, S. H. (2012). Essays on hedge fund performance (p. 116). Doctors: University of Texas-Pan American.

63. Sortino, F. A., \& Van der Meer, R. (1991). Downside Risk. Journal of Portfolio Management, 17(4), 2731.

64. Terhaar, K., Staub, R., \& Singer, B. (2003). Appropriate policy allocation for alternative investments: A factor approach and simulation techniques. Journal of Portfolio Management, 29(3), 101-110.

65. Togher, S., \& Barsbay, T. (2007). Fund of hedge funds portfolio optimization using the Omega ratio, the risk mangement/compliance. The Monitor, The voice of the investment management consultants association.

66. Treynor, J. L. (1965). How to rate management investment funds. Harvard Business Review, 43(1), 63-75.

67. Wong, W.-K., Phoon, K. F., \& Lean, H. H. (2008). Stochastic dominance analysis of Asian hedge funds. Pacific-Basin Financial Journal, 16(3), 204-223.

68. Yahoo Finance. (2013). Supplier of data. Retrieved from: http://finance.yahoo.com/ 


\section{APPENDIX}

Table A: Average Correlation of EU Hedge Funds with the US Hedge Funds

\begin{tabular}{|c|c|c|c|c|c|c|c|c|}
\hline \multicolumn{3}{|c|}{ Pre-Financial Crisis Period } & \multicolumn{3}{|c|}{ During-Financial Crisis Period } & \multicolumn{3}{|c|}{ Post-Financial Crisis Period } \\
\hline EU Hedge Fund & 1 & 0.369 & EU Hedge Fund & 1 & 0.479 & EU Hedge Fund & 1 & 0.394 \\
\hline EU Hedge Fund & 2 & 0.373 & EU Hedge Fund & 2 & 0.484 & EU Hedge Fund & 2 & 0.395 \\
\hline EU Hedge Fund & 3 & 0.313 & EU Hedge Fund & 3 & 0.438 & EU Hedge Fund & 3 & 0.465 \\
\hline EU Hedge Fund & 4 & 0.319 & EU Hedge Fund & 4 & 0.439 & EU Hedge Fund & 4 & 0.478 \\
\hline EU Hedge Fund & 5 & 0.338 & EU Hedge Fund & 5 & 0.501 & EU Hedge Fund & 5 & 0.410 \\
\hline EU Hedge Fund & 6 & 0.342 & EU Hedge Fund & 6 & 0.501 & EU Hedge Fund & 6 & 0.414 \\
\hline EU Hedge Fund & 7 & 0.346 & EU Hedge Fund & 7 & 0.500 & EU Hedge Fund & 7 & 0.412 \\
\hline EU Hedge Fund & 8 & 0.107 & EU Hedge Fund & 8 & -0.082 & EU Hedge Fund & 8 & 0.122 \\
\hline EU Hedge Fund & 9 & 0.280 & EU Hedge Fund & 9 & 0.471 & EU Hedge Fund & 9 & 0.618 \\
\hline EU Hedge Fund & 10 & 0.281 & EU Hedge Fund & 10 & 0.472 & EU Hedge Fund & 10 & 0.609 \\
\hline EU Hedge Fund & 11 & 0.273 & EU Hedge Fund & 11 & 0.343 & EU Hedge Fund & 11 & 0.019 \\
\hline EU Hedge Fund & 12 & 0.367 & EU Hedge Fund & 12 & 0.285 & EU Hedge Fund & 12 & 0.397 \\
\hline EU Hedge Fund & 13 & 0.297 & EU Hedge Fund & 13 & 0.348 & EU Hedge Fund & 13 & 0.075 \\
\hline EU Hedge Fund & 14 & 0.328 & EU Hedge Fund & 14 & 0.518 & EU Hedge Fund & 14 & 0.433 \\
\hline EU Hedge Fund & 15 & 0.334 & EU Hedge Fund & 15 & 0.520 & EU Hedge Fund & 15 & 0.450 \\
\hline EU Hedge Fund & 16 & 0.342 & EU Hedge Fund & 16 & 0.506 & EU Hedge Fund & 16 & 0.449 \\
\hline EU Hedge Fund & 17 & 0.374 & EU Hedge Fund & 17 & 0.480 & EU Hedge Fund & 17 & 0.613 \\
\hline EU Hedge Fund & 18 & 0.358 & EU Hedge Fund & 18 & 0.556 & EU Hedge Fund & 18 & 0.512 \\
\hline EU Hedge Fund & 19 & 0.392 & EU Hedge Fund & 19 & 0.572 & EU Hedge Fund & 19 & 0.586 \\
\hline EU Hedge Fund & 20 & 0.387 & EU Hedge Fund & 20 & 0.510 & EU Hedge Fund & 20 & 0.618 \\
\hline EU Hedge Fund & 21 & 0.267 & EU Hedge Fund & 21 & 0.155 & EU Hedge Fund & 21 & 0.312 \\
\hline EU Hedge Fund & 22 & -0.100 & EU Hedge Fund & 22 & -0.068 & EU Hedge Fund & 22 & 0.292 \\
\hline EU Hedge Fund & 23 & -0.091 & EU Hedge Fund & 23 & -0.048 & EU Hedge Fund & 23 & 0.281 \\
\hline EU Hedge Fund & 24 & 0.350 & EU Hedge Fund & 24 & 0.575 & EU Hedge Fund & 24 & 0.509 \\
\hline EU Hedge Fund & 25 & 0.247 & EU Hedge Fund & 25 & 0.358 & EU Hedge Fund & 25 & 0.625 \\
\hline EU Hedge Fund & 26 & 0.395 & EU Hedge Fund & 26 & 0.480 & EU Hedge Fund & 26 & 0.259 \\
\hline EU Hedge Fund & 27 & 0.410 & EU Hedge Fund & 27 & 0.479 & EU Hedge Fund & 27 & 0.243 \\
\hline EU Hedge Fund & 28 & 0.393 & EU Hedge Fund & 28 & 0.478 & EU Hedge Fund & 28 & 0.259 \\
\hline EU Hedge Fund & 29 & 0.299 & EU Hedge Fund & 29 & 0.099 & EU Hedge Fund & 29 & 0.162 \\
\hline EU Hedge Fund & 30 & 0.299 & EU Hedge Fund & 30 & 0.058 & EU Hedge Fund & 30 & 0.161 \\
\hline EU Hedge Fund & 31 & 0.467 & EU Hedge Fund & 31 & 0.543 & EU Hedge Fund & 31 & 0.463 \\
\hline EU Hedge Fund & 32 & 0.432 & EU Hedge Fund & 32 & 0.578 & EU Hedge Fund & 32 & 0.454 \\
\hline EU Hedge Fund & 33 & 0.112 & EU Hedge Fund & 33 & -0.153 & EU Hedge Fund & 33 & -0.301 \\
\hline EU Hedge Fund & 34 & 0.257 & EU Hedge Fund & 34 & 0.306 & EU Hedge Fund & 34 & 0.410 \\
\hline EU Hedge Fund & 35 & 0.256 & EU Hedge Fund & 35 & 0.312 & EU Hedge Fund & 35 & 0.408 \\
\hline EU Hedge Fund & 36 & 0.254 & EU Hedge Fund & 36 & 0.305 & EU Hedge Fund & 36 & 0.409 \\
\hline EU Hedge Fund & 37 & 0.123 & EU Hedge Fund & 37 & 0.368 & EU Hedge Fund & 37 & 0.248 \\
\hline EU Hedge Fund & 38 & 0.144 & EU Hedge Fund & 38 & 0.381 & EU Hedge Fund & 38 & 0.294 \\
\hline
\end{tabular}

Source: Compiled by authors. 
Table B: Average Correlation of EU Hedge Funds with the Other EU Hedge Funds

\begin{tabular}{|c|c|c|c|c|c|c|c|c|}
\hline \multicolumn{3}{|c|}{ Pre-Financial Crisis Period } & \multicolumn{3}{|c|}{ During-Financial Crisis Period } & \multicolumn{3}{|c|}{ Post-Financial Crisis Period } \\
\hline EU Hedge Fund & 1 & 0.637 & EU Hedge Fund & 1 & 0.537 & EU Hedge Fund & 1 & 0.429 \\
\hline EU Hedge Fund & 2 & 0.634 & EU Hedge Fund & 2 & 0.541 & EU Hedge Fund & 2 & 0.426 \\
\hline EU Hedge Fund & 3 & 0.591 & EU Hedge Fund & 3 & 0.480 & EU Hedge Fund & 3 & 0.472 \\
\hline EU Hedge Fund & 4 & 0.588 & EU Hedge Fund & 4 & 0.476 & EU Hedge Fund & 4 & 0.482 \\
\hline EU Hedge Fund & 5 & 0.541 & EU Hedge Fund & 5 & 0.498 & EU Hedge Fund & 5 & 0.465 \\
\hline EU Hedge Fund & 6 & 0.543 & EU Hedge Fund & 6 & 0.497 & EU Hedge Fund & 6 & 0.464 \\
\hline EU Hedge Fund & 7 & 0.546 & EU Hedge Fund & 7 & 0.496 & EU Hedge Fund & 7 & 0.465 \\
\hline EU Hedge Fund & 8 & 0.227 & EU Hedge Fund & 8 & -0.042 & EU Hedge Fund & 8 & 0.112 \\
\hline EU Hedge Fund & 9 & 0.593 & EU Hedge Fund & 9 & 0.515 & EU Hedge Fund & 9 & 0.539 \\
\hline EU Hedge Fund & 10 & 0.578 & EU Hedge Fund & 10 & 0.513 & EU Hedge Fund & 10 & 0.535 \\
\hline EU Hedge Fund & 11 & 0.459 & EU Hedge Fund & 11 & 0.335 & EU Hedge Fund & 11 & 0.165 \\
\hline EU Hedge Fund & 12 & 0.590 & EU Hedge Fund & 12 & 0.300 & EU Hedge Fund & 12 & 0.303 \\
\hline EU Hedge Fund & 13 & 0.547 & EU Hedge Fund & 13 & 0.333 & EU Hedge Fund & 13 & 0.198 \\
\hline EU Hedge Fund & 14 & 0.591 & EU Hedge Fund & 14 & 0.521 & EU Hedge Fund & 14 & 0.467 \\
\hline EU Hedge Fund & 15 & 0.588 & EU Hedge Fund & 15 & 0.523 & EU Hedge Fund & 15 & 0.478 \\
\hline EU Hedge Fund & 16 & 0.583 & EU Hedge Fund & 16 & 0.518 & EU Hedge Fund & 16 & 0.476 \\
\hline EU Hedge Fund & 17 & 0.548 & EU Hedge Fund & 17 & 0.471 & EU Hedge Fund & 17 & 0.476 \\
\hline EU Hedge Fund & 18 & 0.593 & EU Hedge Fund & 18 & 0.539 & EU Hedge Fund & 18 & 0.412 \\
\hline EU Hedge Fund & 19 & 0.606 & EU Hedge Fund & 19 & 0.551 & EU Hedge Fund & 19 & 0.524 \\
\hline EU Hedge Fund & 20 & 0.518 & EU Hedge Fund & 20 & 0.502 & EU Hedge Fund & 20 & 0.489 \\
\hline EU Hedge Fund & 21 & 0.546 & EU Hedge Fund & 21 & 0.219 & EU Hedge Fund & 21 & 0.226 \\
\hline EU Hedge Fund & 22 & 0.036 & EU Hedge Fund & 22 & -0.070 & EU Hedge Fund & 22 & 0.205 \\
\hline EU Hedge Fund & 23 & 0.039 & EU Hedge Fund & 23 & -0.050 & EU Hedge Fund & 23 & 0.199 \\
\hline EU Hedge Fund & 24 & 0.578 & EU Hedge Fund & 24 & 0.577 & EU Hedge Fund & 24 & 0.386 \\
\hline EU Hedge Fund & 25 & 0.338 & EU Hedge Fund & 25 & 0.372 & EU Hedge Fund & 25 & 0.516 \\
\hline EU Hedge Fund & 26 & 0.595 & EU Hedge Fund & 26 & 0.476 & EU Hedge Fund & 26 & 0.391 \\
\hline EU Hedge Fund & 27 & 0.584 & EU Hedge Fund & 27 & 0.476 & EU Hedge Fund & 27 & 0.383 \\
\hline EU Hedge Fund & 28 & 0.597 & EU Hedge Fund & 28 & 0.475 & EU Hedge Fund & 28 & 0.391 \\
\hline EU Hedge Fund & 29 & 0.497 & EU Hedge Fund & 29 & 0.178 & EU Hedge Fund & 29 & 0.272 \\
\hline EU Hedge Fund & 30 & 0.507 & EU Hedge Fund & 30 & 0.154 & EU Hedge Fund & 30 & 0.274 \\
\hline EU Hedge Fund & 31 & 0.640 & EU Hedge Fund & 31 & 0.509 & EU Hedge Fund & 31 & 0.529 \\
\hline EU Hedge Fund & 32 & 0.656 & EU Hedge Fund & 32 & 0.558 & EU Hedge Fund & 32 & 0.518 \\
\hline EU Hedge Fund & 33 & 0.421 & EU Hedge Fund & 33 & -0.156 & EU Hedge Fund & 33 & -0.263 \\
\hline EU Hedge Fund & 34 & 0.457 & EU Hedge Fund & 34 & 0.331 & EU Hedge Fund & 34 & 0.351 \\
\hline EU Hedge Fund & 35 & 0.457 & EU Hedge Fund & 35 & 0.336 & EU Hedge Fund & 35 & 0.349 \\
\hline EU Hedge Fund & 36 & 0.455 & EU Hedge Fund & 36 & 0.331 & EU Hedge Fund & 36 & 0.349 \\
\hline EU Hedge Fund & 37 & 0.145 & EU Hedge Fund & 37 & 0.316 & EU Hedge Fund & 37 & 0.277 \\
\hline EU Hedge Fund & 38 & 0.154 & EU Hedge Fund & 38 & 0.321 & EU Hedge Fund & 38 & 0.301 \\
\hline
\end{tabular}

Source: Compiled by authors. 
Table C: Average Correlation of US Hedge Funds with the Other US Hedge Funds

\begin{tabular}{|c|c|c|c|c|c|c|c|c|}
\hline \multicolumn{3}{|c|}{ Pre-Financial Crisis Period } & \multicolumn{3}{|c|}{ During-Financial Crisis Period } & \multicolumn{3}{|c|}{ Post-Financial Crisis Period } \\
\hline US Hedge Fund & 1 & 0.282 & US Hedge Fund & 1 & 0.512 & US Hedge Fund & 1 & 0.618 \\
\hline US Hedge Fund & 2 & 0.326 & US Hedge Fund & 2 & 0.482 & US Hedge Fund & 2 & 0.616 \\
\hline US Hedge Fund & 3 & 0.533 & US Hedge Fund & 3 & 0.610 & US Hedge Fund & 3 & 0.608 \\
\hline US Hedge Fund & 4 & 0.139 & US Hedge Fund & 4 & 0.504 & US Hedge Fund & 4 & 0.616 \\
\hline US Hedge Fund & 5 & 0.235 & US Hedge Fund & 5 & 0.573 & US Hedge Fund & 5 & 0.676 \\
\hline US Hedge Fund & 6 & 0.241 & US Hedge Fund & 6 & 0.545 & US Hedge Fund & 6 & 0.672 \\
\hline US Hedge Fund & 7 & 0.448 & US Hedge Fund & 7 & 0.570 & US Hedge Fund & 7 & 0.660 \\
\hline US Hedge Fund & 8 & 0.448 & US Hedge Fund & 8 & 0.573 & US Hedge Fund & 8 & 0.659 \\
\hline US Hedge Fund & 9 & 0.460 & US Hedge Fund & 9 & 0.525 & US Hedge Fund & 9 & 0.555 \\
\hline US Hedge Fund & 10 & 0.410 & US Hedge Fund & 10 & 0.498 & US Hedge Fund & 10 & 0.541 \\
\hline US Hedge Fund & 11 & 0.320 & US Hedge Fund & 11 & 0.458 & US Hedge Fund & 11 & 0.318 \\
\hline US Hedge Fund & 12 & -0.163 & US Hedge Fund & 12 & 0.077 & US Hedge Fund & 12 & -0.277 \\
\hline US Hedge Fund & 13 & 0.329 & US Hedge Fund & 13 & 0.594 & US Hedge Fund & 13 & 0.631 \\
\hline US Hedge Fund & 14 & 0.511 & US Hedge Fund & 14 & 0.471 & US Hedge Fund & 14 & 0.605 \\
\hline US Hedge Fund & 15 & 0.509 & US Hedge Fund & 15 & 0.470 & US Hedge Fund & 15 & 0.604 \\
\hline US Hedge Fund & 16 & 0.460 & US Hedge Fund & 16 & 0.570 & US Hedge Fund & 16 & 0.621 \\
\hline US Hedge Fund & 17 & 0.183 & US Hedge Fund & 17 & 0.558 & US Hedge Fund & 17 & 0.556 \\
\hline US Hedge Fund & 18 & 0.336 & US Hedge Fund & 18 & 0.347 & US Hedge Fund & 18 & 0.660 \\
\hline US Hedge Fund & 19 & 0.493 & US Hedge Fund & 19 & 0.552 & US Hedge Fund & 19 & 0.592 \\
\hline US Hedge Fund & 20 & 0.441 & US Hedge Fund & 20 & 0.536 & US Hedge Fund & 20 & 0.521 \\
\hline US Hedge Fund & 21 & 0.335 & US Hedge Fund & 21 & 0.462 & US Hedge Fund & 21 & 0.675 \\
\hline US Hedge Fund & 22 & 0.244 & US Hedge Fund & 22 & 0.473 & US Hedge Fund & 22 & 0.563 \\
\hline US Hedge Fund & 23 & 0.422 & US Hedge Fund & 23 & 0.516 & US Hedge Fund & 23 & 0.615 \\
\hline US Hedge Fund & 24 & 0.367 & US Hedge Fund & 24 & 0.570 & US Hedge Fund & 24 & 0.419 \\
\hline US Hedge Fund & 25 & 0.412 & US Hedge Fund & 25 & 0.509 & US Hedge Fund & 25 & 0.529 \\
\hline US Hedge Fund & 26 & 0.413 & US Hedge Fund & 26 & 0.506 & US Hedge Fund & 26 & 0.527 \\
\hline US Hedge Fund & 27 & 0.414 & US Hedge Fund & 27 & 0.517 & US Hedge Fund & 27 & 0.533 \\
\hline US Hedge Fund & 28 & 0.408 & US Hedge Fund & 28 & 0.523 & US Hedge Fund & 28 & 0.282 \\
\hline US Hedge Fund & 29 & 0.539 & US Hedge Fund & 29 & 0.591 & US Hedge Fund & 29 & 0.673 \\
\hline US Hedge Fund & 30 & 0.385 & US Hedge Fund & 30 & 0.312 & US Hedge Fund & 30 & 0.650 \\
\hline US Hedge Fund & 31 & 0.394 & US Hedge Fund & 31 & 0.419 & US Hedge Fund & 31 & 0.561 \\
\hline US Hedge Fund & 32 & -0.035 & US Hedge Fund & 32 & 0.008 & US Hedge Fund & 32 & 0.325 \\
\hline US Hedge Fund & 33 & 0.518 & US Hedge Fund & 33 & 0.538 & US Hedge Fund & 33 & 0.547 \\
\hline US Hedge Fund & 34 & 0.528 & US Hedge Fund & 34 & 0.606 & US Hedge Fund & 34 & 0.679 \\
\hline US Hedge Fund & 35 & 0.544 & US Hedge Fund & 35 & 0.536 & US Hedge Fund & 35 & 0.674 \\
\hline US Hedge Fund & 36 & 0.425 & US Hedge Fund & 36 & 0.462 & US Hedge Fund & 36 & 0.464 \\
\hline US Hedge Fund & 37 & 0.341 & US Hedge Fund & 37 & 0.501 & US Hedge Fund & 37 & 0.560 \\
\hline US Hedge Fund & 38 & 0.379 & US Hedge Fund & 38 & 0.494 & US Hedge Fund & 38 & 0.552 \\
\hline US Hedge Fund & 39 & 0.467 & US Hedge Fund & 39 & 0.487 & US Hedge Fund & 39 & 0.616 \\
\hline US Hedge Fund & 40 & 0.431 & US Hedge Fund & 40 & 0.547 & US Hedge Fund & 40 & 0.129 \\
\hline US Hedge Fund & 41 & 0.301 & US Hedge Fund & 41 & 0.211 & US Hedge Fund & 41 & 0.624 \\
\hline US Hedge Fund & 42 & 0.301 & US Hedge Fund & 42 & 0.210 & US Hedge Fund & 42 & 0.624 \\
\hline US Hedge Fund & 43 & 0.302 & US Hedge Fund & 43 & 0.220 & US Hedge Fund & 43 & 0.625 \\
\hline US Hedge Fund & 44 & 0.406 & US Hedge Fund & 44 & 0.159 & US Hedge Fund & 44 & -0.298 \\
\hline US Hedge Fund & 45 & 0.320 & US Hedge Fund & 45 & 0.464 & US Hedge Fund & 45 & 0.436 \\
\hline US Hedge Fund & 46 & 0.008 & US Hedge Fund & 46 & 0.299 & US Hedge Fund & 46 & 0.365 \\
\hline US Hedge Fund & 47 & 0.025 & US Hedge Fund & 47 & 0.299 & US Hedge Fund & 47 & 0.365 \\
\hline US Hedge Fund & 48 & 0.446 & US Hedge Fund & 48 & 0.348 & US Hedge Fund & 48 & 0.582 \\
\hline US Hedge Fund & 49 & 0.321 & US Hedge Fund & 49 & 0.313 & US Hedge Fund & 49 & 0.578 \\
\hline US Hedge Fund & 50 & 0.512 & US Hedge Fund & 50 & 0.571 & US Hedge Fund & 50 & 0.662 \\
\hline US Hedge Fund & 51 & 0.321 & US Hedge Fund & 51 & 0.312 & US Hedge Fund & 51 & 0.578 \\
\hline US Hedge Fund & 52 & 0.483 & US Hedge Fund & 52 & 0.585 & US Hedge Fund & 52 & 0.680 \\
\hline US Hedge Fund & 53 & 0.519 & US Hedge Fund & 53 & 0.588 & US Hedge Fund & 53 & 0.677 \\
\hline US Hedge Fund & 54 & 0.515 & US Hedge Fund & 54 & 0.605 & US Hedge Fund & 54 & 0.672 \\
\hline US Hedge Fund & 55 & 0.542 & US Hedge Fund & 55 & 0.596 & US Hedge Fund & 55 & 0.675 \\
\hline
\end{tabular}


Table $\mathbf{C}$ cont.

\begin{tabular}{|c|c|c|c|c|c|c|c|c|}
\hline US Hedge Fund & 56 & 0.338 & US Hedge Fund & 56 & 0.489 & US Hedge Fund & 56 & 0.679 \\
\hline US Hedge Fund & 57 & -0.115 & US Hedge Fund & 57 & 0.050 & US Hedge Fund & 57 & -0.064 \\
\hline US Hedge Fund & 58 & 0.352 & US Hedge Fund & 58 & 0.375 & US Hedge Fund & 58 & 0.279 \\
\hline US Hedge Fund & 59 & 0.448 & US Hedge Fund & 59 & 0.565 & US Hedge Fund & 59 & 0.570 \\
\hline US Hedge Fund & 60 & 0.415 & US Hedge Fund & 60 & 0.426 & US Hedge Fund & 60 & 0.328 \\
\hline US Hedge Fund & 61 & 0.415 & US Hedge Fund & 61 & 0.420 & US Hedge Fund & 61 & 0.325 \\
\hline US Hedge Fund & 62 & 0.418 & US Hedge Fund & 62 & 0.416 & US Hedge Fund & 62 & 0.303 \\
\hline US Hedge Fund & 63 & 0.422 & US Hedge Fund & 63 & 0.429 & US Hedge Fund & 63 & 0.331 \\
\hline US Hedge Fund & 64 & 0.045 & US Hedge Fund & 64 & 0.351 & US Hedge Fund & 64 & 0.358 \\
\hline US Hedge Fund & 65 & 0.062 & US Hedge Fund & 65 & 0.348 & US Hedge Fund & 65 & 0.347 \\
\hline US Hedge Fund & 66 & 0.516 & US Hedge Fund & 66 & 0.540 & US Hedge Fund & 66 & 0.661 \\
\hline US Hedge Fund & 67 & 0.467 & US Hedge Fund & 67 & 0.463 & US Hedge Fund & 67 & 0.504 \\
\hline US Hedge Fund & 68 & 0.271 & US Hedge Fund & 68 & 0.223 & US Hedge Fund & 68 & 0.420 \\
\hline US Hedge Fund & 69 & 0.452 & US Hedge Fund & 69 & 0.348 & US Hedge Fund & 69 & 0.529 \\
\hline US Hedge Fund & 70 & 0.353 & US Hedge Fund & 70 & 0.149 & US Hedge Fund & 70 & 0.385 \\
\hline US Hedge Fund & 71 & 0.355 & US Hedge Fund & 71 & 0.152 & US Hedge Fund & 71 & 0.385 \\
\hline US Hedge Fund & 72 & 0.489 & US Hedge Fund & 72 & 0.537 & US Hedge Fund & 72 & 0.650 \\
\hline US Hedge Fund & 73 & 0.422 & US Hedge Fund & 73 & 0.542 & US Hedge Fund & 73 & 0.680 \\
\hline US Hedge Fund & 74 & 0.409 & US Hedge Fund & 74 & 0.356 & US Hedge Fund & 74 & 0.545 \\
\hline US Hedge Fund & 75 & 0.413 & US Hedge Fund & 75 & 0.357 & US Hedge Fund & 75 & 0.547 \\
\hline US Hedge Fund & 76 & 0.434 & US Hedge Fund & 76 & 0.561 & US Hedge Fund & 76 & 0.639 \\
\hline US Hedge Fund & 77 & 0.205 & US Hedge Fund & 77 & 0.508 & US Hedge Fund & 77 & 0.603 \\
\hline US Hedge Fund & 78 & 0.262 & US Hedge Fund & 78 & 0.425 & US Hedge Fund & 78 & 0.521 \\
\hline US Hedge Fund & 79 & -0.085 & US Hedge Fund & 79 & -0.251 & US Hedge Fund & 79 & -0.090 \\
\hline US Hedge Fund & 80 & 0.343 & US Hedge Fund & 80 & 0.482 & US Hedge Fund & 80 & 0.615 \\
\hline US Hedge Fund & 81 & 0.474 & US Hedge Fund & 81 & 0.482 & US Hedge Fund & 81 & 0.642 \\
\hline US Hedge Fund & 82 & 0.525 & US Hedge Fund & 82 & 0.537 & US Hedge Fund & 82 & 0.652 \\
\hline US Hedge Fund & 83 & 0.523 & US Hedge Fund & 83 & 0.536 & US Hedge Fund & 83 & 0.651 \\
\hline US Hedge Fund & 84 & -0.014 & US Hedge Fund & 84 & -0.070 & US Hedge Fund & 84 & -0.198 \\
\hline
\end{tabular}

Source: Compiled by authors. 


\section{NOTES}

